\title{
Mining Activities and The Chemical Composition of R. Modonkul, Transbaikalia
}

\author{
Zinaida Ivanovna Khazheeva, Aleksey Maksimovich Plyusnin and Seseg Sergeevna Sanzhanova * \\ Geological Institute of SB RAS, Ulan-Ude; zkhazh@geo.stbur.ru (Z.I.K.); plyusnin@ginst.ru (A.M.P.) \\ * Correspondence: sanzhanova@geo.stbur.ru; Tel.: +79516213498
}

\begin{abstract}
The paper presents the results of observations of the spatial variability of the chemical composition of the river Modonkul. According to these observations, the chemical composition changes from bicarbonate calcium-magnesium in the upper part of the river through sulfate-calcium-sodium (and other transitional differences) to sulfate-calcium-magnesium type in the river's mouth. Redistribution of dissolved and suspended forms of migration heavy metals occurs in the alkaline environment in river Modonkul. The data of the content rare earth elements in water river are obtained.
\end{abstract}

Keywords: acid mine, change of the chemical type of water, alkaline barrier, precipitation of hydroxides, sorption of heavy metals

\section{Introduction}

In the South -Western Transbaikalia (Russia), there are numerous economic Mo-W deposites that constitute the Dzhidinskoe ore field (N50'19'; E10321'). This ore field includes Pervomaiskoye Mo, Inkurskoe $\mathrm{W}$ and Kholtosonskoye $\mathrm{W}$ deposits and is charachterized by a large metal resource spreading over a relatively small are [1]. The three deposits are unique geological objects and are the largest sources of W and Mo in Russia. All the deposits are genetically related to a single porphyry granitoid intrusion (Pervomaisky stock). Formation of the stockwork Mo-W mineralization occurred during several hydrothermal stages which were separated in time by intrusive magmatism. First, the Mo stockwork representing Pervomaiskoye molybdenum deposit formed along with minor Mo-Be mineralization. After wards the stockwork of hubnerite - bearing vienlets in the Inkurskoe tungsten deposit formed. This was followed by the formation of the stockwork of hubnerite - bearing vienlets in the Inkurskoe tungsten deposit. The latest stage of ore formation is represented by quartz-hubnerite veins of the Kholtosonskoye tungsten deposit [2,3].

In last thirty years studied and published the results relating to acid rock drainage due to the presence of sulfide bearing minerals in active. Prediction and prevention are the best strategy in handing mine drainage problem and minimize its environmental impact [4-7].

\section{Materials and Methods}

\subsection{Study Area}

The catchment area of the Modonkul river is located on the territory of the Dzhidinsky ore field in Transbaikalia (Republic of Buryatia). The river is first-order tributary of river Dzhida. The Modonkul river is characterized by the following hydrological parameters: area $170 \mathrm{~km}^{2}$, length $\mathrm{L}=8$ $\mathrm{km}$, average annual water discharge $\mathrm{Q}=0.80 \mathrm{~km}^{3} / \mathrm{s}$, water flow volume $\mathrm{W}=0.025 \mathrm{~km}^{3}$. Zakamensk city is the center of Dzhidinski economic zone, which has a large proportion of the Buryat population is the main animal-breeding zone of the republic. Until recently, its main industrial center was Dzhida tungsten-molybdenum plant, which is currently struggling. The industrial nucleus of the zone is separated from its agrarian periphery.

The average temperature varied from $-24^{\circ} \mathrm{C}$ in January to $18.9^{\circ} \mathrm{C}$ in July. The average annual rainfall ranges $280 \mathrm{~mm}$ in 2004 to $320 \mathrm{~mm}$ in 2012 years. Moreover, 90\% of annual precipitation occurs in summer, which brings out frequent floods causing lots of damage in summer and severe 
shortage of water during the rest of the year. This river provides one of major water supply in this basin. $20-60 \%$ of wastewater is treated and untreated wastewater is returned to this river.

\subsection{Sampling Site and Sample Analysis}

A total of 80 samples of water and suspended materials were collected at sites M1-M7 (Fig.1). Surface water $(0-0.5 \mathrm{~m})$ was collected monthly during 2007-2016 years. The water samples were immediately preserved in $1 \mathrm{~L}$ polypropylene sampling bottles at $4^{\circ} \mathrm{C}$ in darkness and analyzed within $48 \mathrm{~h}$. The samples were filtrated by $0.45 \mu \mathrm{m}$ filter and divided into soluble water samples and insoluble (particle samples) for $\mathrm{Fe}, \mathrm{Mn}, \mathrm{Pb}, \mathrm{Cu}, \mathrm{Zn}, \mathrm{As}, \mathrm{Cd}$ analysis. Filtrate samples were digested by with of $\mathrm{HNO}_{3}$ up $\mathrm{pH} 2$ then was used for determination of dissolved heavy trace elements and REE. The parameters of water quality included suspended solids (SS), conductivity (Cond), dissolved oxygen (DO), $\mathrm{pH}$, chemical oxygen demand (COD), biologic oxygen demand (BOD), total nitrogen $(\mathrm{TN})$, ammonium nitrogen $\left(\mathrm{NH}_{4}-\mathrm{N}\right)$, total phosphates (TP), petroleum (Petro) and volatile phenolics (V-phen). The $\mathrm{pH}$, conductivity, and $\mathrm{DO}$ were determined directly at each sampling site. The conductivity was measured with YSI meter Model 33 (YSI, USA), the $\mathrm{pH}$ was measured by a $\mathrm{pH}$ meter Beckman Model F8253 (Beckman, USA), and the DO was measured by a YSI oxygen meter Model 57 (YSI, USA).

The water analyzed in the water analysis laboratory of the Geological Institute Siberian Branch of Russian Academy of Sciences (GIN SB RAS). Water quality parameters were determined by the following methods: $\mathrm{Ca}^{2+}, \mathrm{Mg}^{2+}$ - complexonometry, $\mathrm{Na}^{+}+\mathrm{K}^{+}$- flame-photometer of M7D type, $\mathrm{CO}_{3}{ }^{2-}$, $\mathrm{HCO}_{3}{ }^{-}$-volumetric, $\mathrm{Cl}^{-}$-argentometry, $\mathrm{SO}_{4}{ }^{2-}$ - weight, oxidation of permanganate - permanganate. Major cations of water samples collected in 2008 year were determined with another ion chromatograph (ICS-2500, Dinex) and major anions except $\mathrm{HCO}_{3}^{-}$were measured by ICS-2000. $\mathrm{HCO}_{3}{ }^{-}$concentration was estimated from the ion balance of major cations and anions. Trace elements and REE was measured using inductively coupled plasma mass spectrometry (ELEMENT XR, Thermo Finigan, Germany), insoluble heavy metals was measured using atomic adsorption spectrophotometer AAC Pin AAcle 900F at the «Analytical center of mineralogical, geochemical and isotope studies» of the Geological Institute of the Siberian Branch of the Russian Academy of Sciences (Ulan-Ude, Russia). The SS, COD, BOD, TN, TP, NH4-N were determined using standard methods. Petro was measured using Infrared Spectrophotometry, and V-pen was measured using Flow Injection- Spectrophotometry [8]. 


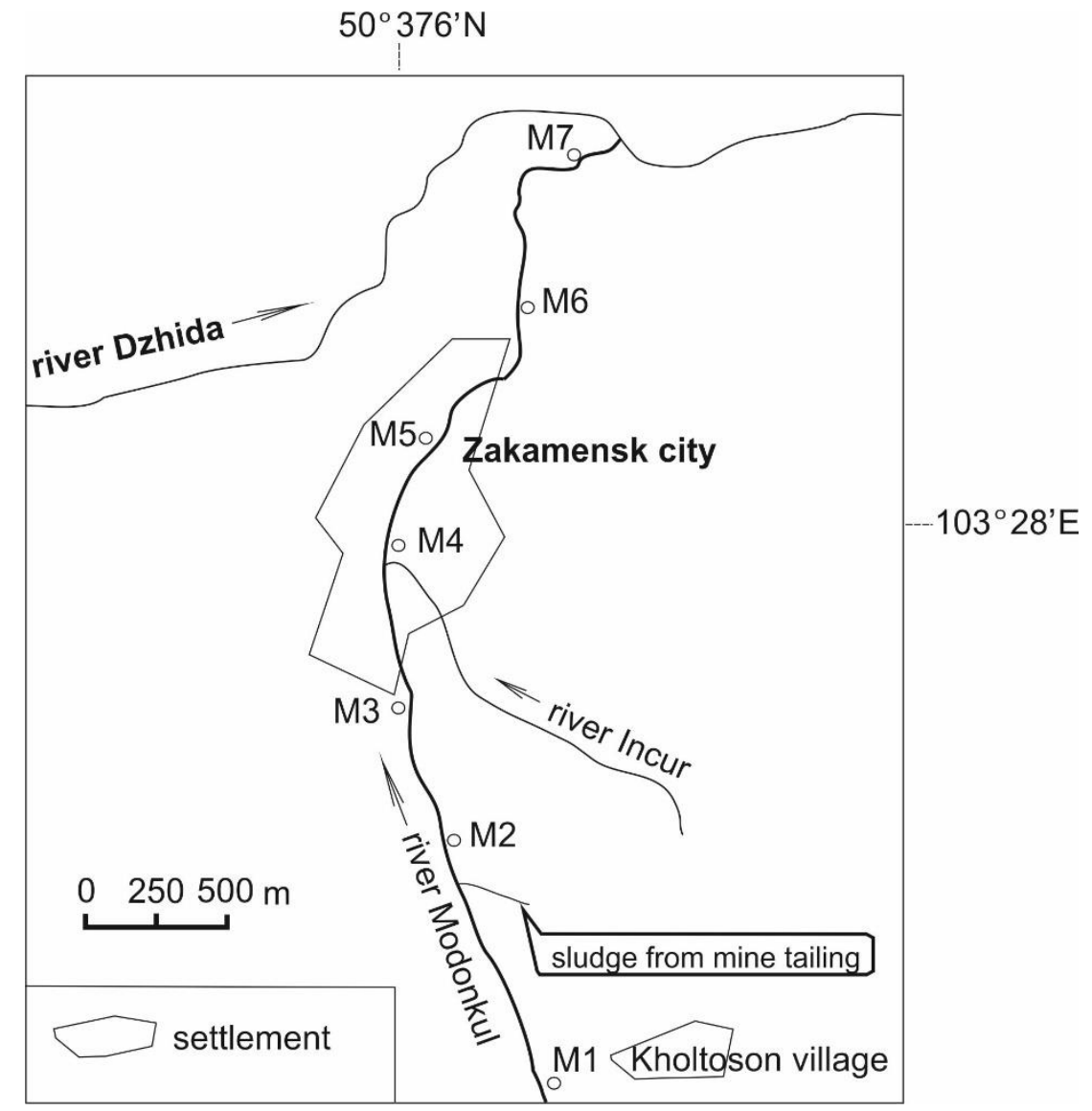

Figure 1. Location of sampling sites.

\subsection{Data Analysis}

The final results of contents $C_{i}$ calculated as: $C_{i}=\frac{\sum_{n}^{8} C_{n} Q_{n}}{\sum_{n}^{10} Q_{n}}$, where $Q_{n}$ is water discharge at the sampling site. The top number giving the monthly ranges of variations of weighted mean concentrations, the bottom number giving the mean many-year concentration in the observation period, calculated as the arithmetic mean of weighted mean concentrations at the observation within the year. To complete the analyzed data, materials of Buryat Department of Hydrometeorological Servic (BDHMS) for years 2006 to 2015 were used.

\section{Results and Discussion}

\subsection{Main Ions and Total Dissolved Solids (TDS)}

Piper's diagram was used to describe the concentration or relative abundance of major and minor constituents and as the pattern of variability in water samples. The relative abundance of cations with the equiv. $\%$ of $\mathrm{Na}^{+}, \mathrm{K}^{+}, \mathrm{Ca}^{2+}$, and $\mathrm{Mg}^{2+}$ is first plotted on the cation triangle. The relative abundance of $\mathrm{Cl}^{-}, \mathrm{SO}_{4}^{2-}$, and $\mathrm{HCO}_{3}{ }^{-}$is then plotted on the anion triangle (Fig. 2). The highest concentrations with corresponding sites are as follows: $\mathrm{HCO}_{3-}^{-} \mathrm{M} 1$; $\mathrm{SO}_{4^{2-}}-\mathrm{M} 2, \mathrm{M} 6, \mathrm{M} 7$; $\mathrm{Ca}^{2+}-\mathrm{M} 1$, M3, M4, M6, M7; $\mathrm{Mg}^{2+}-\mathrm{M} 1 ; \mathrm{Na}^{+}+\mathrm{K}^{+}-\mathrm{M} 2$. The cation composition is dominated by Ca at the site M3, M4, M5, M6, M7. In the anion composition is dominated by bicarbonate at the M1, M3, M5. Sulfate is higher at M2, M4, M6, M7 (Table 1). 

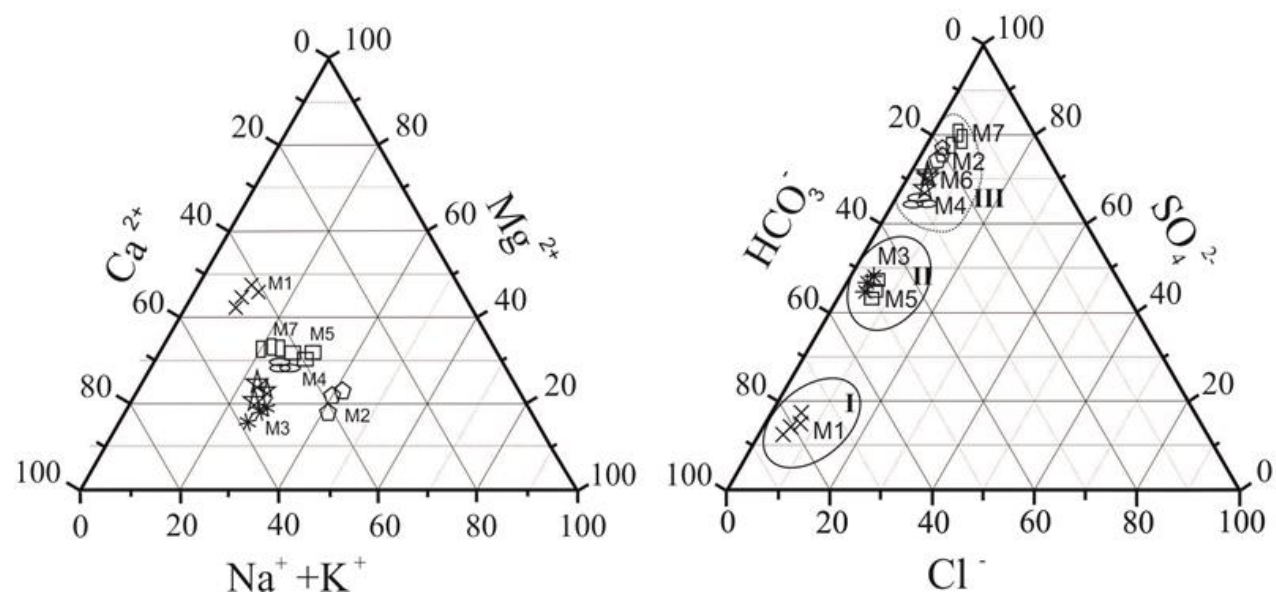

Figure 2. Ternary plots of the chemical composition of water river Modonkul.

Table 1. Ion composition (equiv. \%) and TDS $\left(\mathrm{mg} \mathrm{l}^{-1}\right)$ for water samples from river Modonkul.

\begin{tabular}{cccccccc}
\hline Site & M1 & M2 & M3 & M4 & M5 & M6 & M7 \\
\hline $\mathrm{HCO}_{3}^{-} / \mathrm{TZ}^{-}$ & 78.15 & 20.53 & 49.69 & 30.14 & 48.83 & 25.99 & 16.35 \\
\hline $\mathrm{SO}_{4}^{2-} / \mathrm{TZ}^{-}$ & 14.70 & 75.84 & 46.06 & 65.28 & 44.28 & 70.06 & 78.65 \\
\hline $\mathrm{Cl}^{-} / \mathrm{TZ}^{-}$ & 7.15 & 3.64 & 4.26 & 4.59 & 6.90 & 3.95 & 5.01 \\
\hline $\mathrm{Ca}^{2+} / \mathrm{TZ}^{+}$ & 40.57 & 36.55 & 53.40 & 46.90 & 38.26 & 50.39 & 43.36 \\
\hline $\mathrm{Mg}^{2+} / \mathrm{TZ}^{+}$ & 47.19 & 22.07 & 18.53 & 25.23 & 30.95 & 23.86 & 33.56 \\
\hline$\left(\mathrm{Na}^{+}+\mathrm{K}^{+} / \mathrm{TZ}^{+}\right.$ & 11.02 & 40.71 & 26.83 & 27.26 & 30.02 & 25.26 & 22.68 \\
\hline $\mathrm{TDS}$ & $169-182$ & $480-862$ & $218-246$ & $286-367$ & $264-328$ & $726-862$ & $684-743$ \\
\hline
\end{tabular}

Note: $\mathrm{TZ}^{+}$and $\mathrm{TZ}^{-}$stand for total cations and total anions respectively.

In Figure 2 all points are distributed along the $\mathrm{HCO}_{3}{ }^{-}$axis, showing insignificant concentration

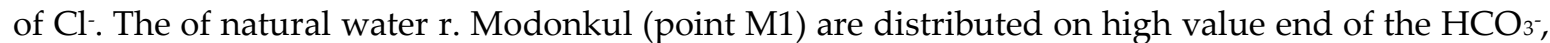
showing the absolutely predominant proportion in the anion composition, $\mathrm{SO}_{4}{ }^{2-}$ only occupies $14 \%$ in ellipse I. In downstream the points M3, M5 are in ellipse II, located on the lower position of $\mathrm{HCO}_{3}{ }^{-}$ axis, showing decrease of $\mathrm{HCO}_{3}{ }^{-}$and increase of $\mathrm{SO}_{4}{ }^{2-}$ ( occupying 44-46\%). The points $\mathrm{M} 2, \mathrm{M} 4, \mathrm{M} 6$, $\mathrm{M} 7$ are in ellipse III, where $\mathrm{SO}_{4}{ }^{2-}$ accounts for $65-78 \%$.

There are great variations among the TDS in different inflows. The TDS of water mine tailing is as high as 1984-2107 $\mathrm{mg} \mathrm{l}^{-1}, \mathrm{pH} 3.44-5.23$, content $\mathrm{F}$ 21.6-62.3 $\mathrm{mg} \mathrm{l}^{-1}$. The TDS of river Incur is 1348-1482 $\mathrm{mg} \mathrm{l}^{-1}$, $\mathrm{pH}$ 6.8-7.4, content $\mathrm{F} 34.6-67.2 \mathrm{mg} \mathrm{l}^{-1}$.

Natural water r. Modonkul (site M1) is fresh, bicarbonate calcium-magnesium with a mineralization of 169-182 $\mathrm{mg} \mathrm{l}^{-1}$, $\mathrm{pH}$ 7.1-7.6, the molar ratios $\left(\mathrm{Ca}^{2+}+\mathrm{Mg}^{2+}\right) / \mathrm{HCO}^{-} \approx 1.2$. The fluoride content is $2.72 \mathrm{mg} \mathrm{l}^{-1}$.

In the natural water $\mathrm{r}$. Modonkul the cations and anions are arranged in decreasing order of

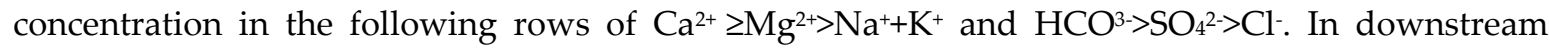
anion composition was changed, showing increase of $\mathrm{SO}_{4}{ }^{2-}$. As results along the river the chemical composition of water changes from $\mathrm{HCO}^{3--} \mathrm{Ca}^{2+}-\mathrm{Mg}^{2+}$ at the site $\mathrm{M} 1$ to $\rightarrow \mathrm{SO}_{4}^{2-}-\mathrm{HCO}^{3--} \mathrm{Ca}^{2+-} \mathrm{Na}^{+}$at the site $\mathrm{M} 2 \rightarrow \mathrm{SO}_{4}^{2--} \mathrm{Ca}^{2+-} \mathrm{Mg}^{2+}$ at the site $\mathrm{M} 7$.

The greatest change in acid-alcaline conditions occurs in the site M2 after confluence mine water. The $\mathrm{pH}$ values of the water Modonlul decreases from 7.3 to 6.47. In downstream $\mathrm{pH}$ values showed less variation, ranging from 7.0 to 7.63. There are great variations among the TDS in different sites M2 - 3, M4 - 1.8, M6 - 4.7, M7 - 4.1 times regarding natural water river at the site M1. The increase in the amount of salts in water is due to a sharp increase the content of sulfate-ions and the associated equivalent amount of cations. The sulfate-ions increased at site M2 - by 14.6, M4 - by 8.2, M6 - by 23.7, M7 - by 23.4 times, $\mathrm{HCO}^{3-}$ - ions decreased by 1.1-1.3 times, chloride content increased by M2 - 1.4, M4 - 1.2, M6 - 2.8, M7 - 3.1 times, fluoride content increased by M2 - 26.1, M4 - 
5.8, M6 - 10.4, M7 - 10.5 times regarding the site M1. The molar ratios $\left(\mathrm{Ca}^{2+}+\mathrm{Mg}^{2+}\right) / \mathrm{HCO}_{3}{ }^{-}$is about 2 at the sites M3 and M5 where the chemical composition of water $\mathrm{HCO}^{3-}-\mathrm{SO}_{4}^{2--} \mathrm{Ca}^{2+}-\mathrm{Na}^{+}$and is much more than 2 for composition $\mathrm{SO}_{4}^{2--} \mathrm{HCO}^{3-}-\mathrm{Na}^{+}-\mathrm{Ca}^{2+}$ at the sites M2, M4, M6. There are coincidence in spatial variations of contents $\mathrm{F}$ and molar ratios $\left(\mathrm{Ca}^{2+}+\mathrm{Mg}^{2+}\right) / \mathrm{HCO}_{3}$ (Fig. 3).

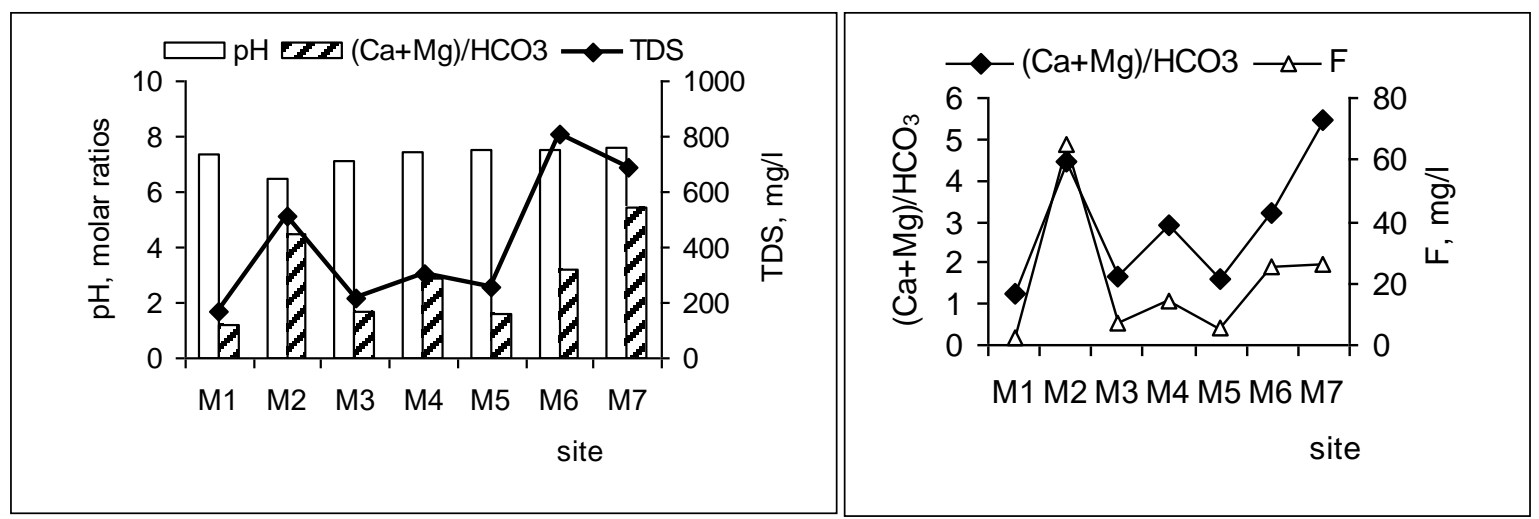

Figure 3. Spatial distribution of $\mathrm{pH}$, molar ratios $\left(\mathrm{Ca}^{2+}+\mathrm{Mg}^{2+}\right) / \mathrm{HCO}_{3}^{-}$, TDS and fluoride content.

Thus, along the river the chemical composition of water changes from $\mathrm{HCO}^{3--} \mathrm{Ca}^{2+}-\mathrm{Mg}^{2+}$ at the upper to $\rightarrow \mathrm{SO}_{4}{ }^{2-}-\mathrm{Ca}^{2+}-\mathrm{Na}^{+} \rightarrow \mathrm{SO}_{4}{ }^{2-}-\mathrm{Ca}^{2+}-\mathrm{Mg}^{2+}$ at the mouth. Ternary plots and ionic ratios not only revealed that water ions origin from the weathering of carbonate, pyrite and silicate, but show the impact of the recharged inflows. The spatial variation of the composition water $r$. Modoncul are revealed the conversion from absolutely bicarbonate to predominant proportion of sulfate among the anions. The difference of hydrochemical composition in river has close relationship with the flux of the recharged inflows.

Organic and biogenic parameters of water quality of river are represented as follow. The highest DO level (11.68 $\left.\mathrm{mg} \mathrm{l}^{-1}\right)$ was found in December, the lowest level (6.8-7.1 $\left.\mathrm{mg} \mathrm{l}^{1-1}\right)$ - in July. The COD contents were found 11.3-24.0, relatively high in summer $17.8-24.0 \mathrm{mg} \mathrm{l}^{-}$, the BOD contents are $0.9-4.8 \mathrm{mg} \mathrm{l}^{-}$showed a similar trend. The concentration of TN $\left(0.21-1.81 \mathrm{mg} \mathrm{l}^{-1}\right), \mathrm{N}^{-N_{4}}(0.03-0.61 \mathrm{mg}$ $\left.\mathrm{1}^{-1}\right)$ and TP (0.01-0.03 $\left.\mathrm{mg} \mathrm{l}^{-1}\right)$. The highest concentrations of Petro are 0.03-0.05 mg 1-1, V-phen are $0.001-0.002 \mathrm{mg} \mathrm{l}^{-1}$. The average content of TOC was $1.78 \%$.

\subsection{Heavy Metals}

The mixing of acid mine waters ( $\mathrm{pH}$ 2.86-4.58) with natural river water $\mathrm{pH}$ 7.08-7.21 has lead to the changes of $\mathrm{pH}$ values of water river up to 6.47-6.74 and dissolved oxygen in the water, which due to significant variations in their chemical compositions and suspended loads In natural water of river dissolved concentrations of heavy metals (site M1) are ( $\left.\mu^{-1} \mathrm{l}^{-1}\right)$ : Fe - 28.5, Mn-6.8, Cu-7.7, $\mathrm{Zn}-11.1, \mathrm{~Pb}-1.2, \mathrm{Cd}-0.08$. In water of Modokul under the increasing $\mathrm{pH}$ value and dissolved oxygen hydroxides of $\mathrm{Fe}, \mathrm{Al}, \mathrm{Mn}$ precipitates in sediment. After the inflows mine water (site M2) the dissolved heavy metals increased $\mathrm{Zn}$ by $22-29, \mathrm{Cu}, \mathrm{Mn}$ by $9-12, \mathrm{~Pb}, \mathrm{Cd}$ by $2-6$ times regarding the site M1, at the same time, the concentrations of dissolved Fe decreases by 3-6 times (Fig. 4). At this time, the particle form of migration heavy metals is increased $\mathrm{Fe}, \mathrm{Mn}, \mathrm{Zn}$ by $60-110, \mathrm{Cu}, \mathrm{Pb}$ by $15-23$, $\mathrm{Ni}, \mathrm{Cd}$ by 2-6 times at site M2 (Fig. 5). At the sites M3-M5 the concentrations of dissolved heavy metals fall to values 2.1-3.5 times higher than in natural water (site M1). At the site M7 the concentrations of dissolved heavy metal exceeded the content in natural water (site M1): $\mathrm{Fe}-2-3$ times; $\mathrm{Mn}-8-10$ times; $\mathrm{Zn}-11-14$ times; $\mathrm{Cu}-3-5$ times; $\mathrm{Ni}, \mathrm{Cd}-1.5-2$ times. 


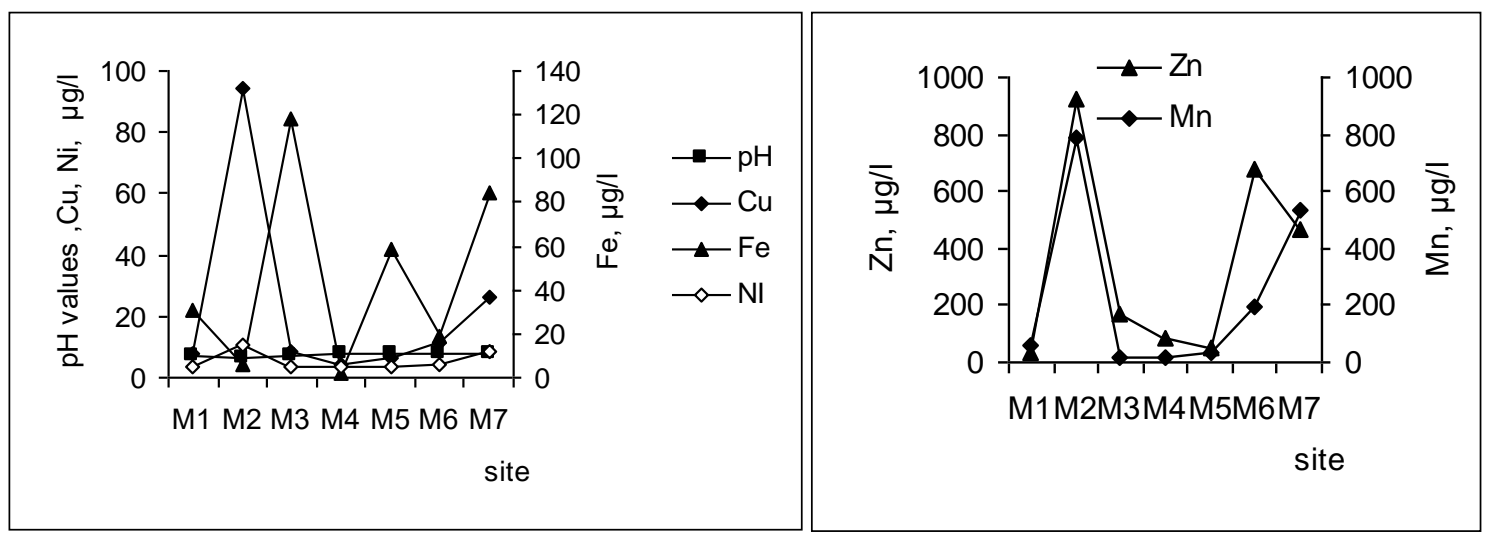

Figure 4. Spatial distribution of dissolved $\mathrm{Fe}, \mathrm{Mn}, \mathrm{Zn}, \mathrm{Cu}, \mathrm{Ni}$ and $\mathrm{pH}$ values.

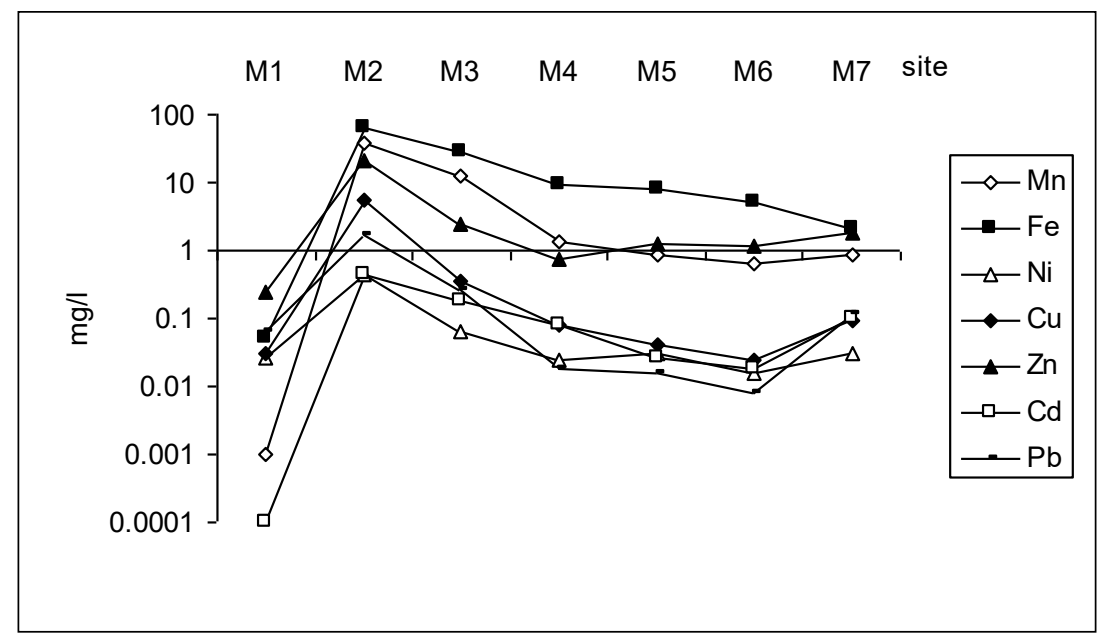

Figure 5. Spatial distribution of particles $\mathrm{Fe}, \mathrm{Mn}, \mathrm{Zn}, \mathrm{Cu}, \mathrm{Ni}, \mathrm{Cd}$.

In previous studies have shown that in acid mine drainage hydroxide complexes are predominant species for iron. There is the change in the predominant hydroxide species with $\mathrm{pH}$. Under the $\mathrm{pH}$ up to 7.10 the $\mathrm{Fe}(\mathrm{OH}) 2^{+}$predominates and under the most basic conditions, the $\mathrm{Fe}(\mathrm{OH})_{3}{ }^{0}$ predominates. The proportion of $\mathrm{Fe}(\mathrm{OH})_{4}$ is $<1 \%$ even in the solution with $\mathrm{pH}=7.5$. Aqueous species of $\mathrm{Mn}$ in solutions are more diverse, but free $\mathrm{Mn}^{2+}(76-86 \%)$ are the predominant species. Proportions of $\mathrm{MnCO}_{3 q^{9}}{ }^{0}$ (up to $10 \%$ ) and $\mathrm{MnHCO}_{3}{ }^{+}$up to $8 \%$ ) are meaningful all over the $\mathrm{pH}$. The proportion of $\mathrm{MnSO}_{4}{ }^{0}$ amounts to 15 and at $\mathrm{pH}<7.10$ begins to increase gradually up to $19 \%$ [4].

The calculation of dissolved species of elements in solutions after the intensive oxidation procedure shows how the species of elements can be changed over time. The $\mathrm{Fe}^{2+}$ is predominant species in the range of $\mathrm{pH}$ 2.93-4.27. The $\mathrm{Fe}(\mathrm{OH})_{2}{ }^{+}$accounts for $91 \%$ when the $\mathrm{pH}$ is greater than 5.09 . Free $\mathrm{Mn}^{2+}$ is the predominant species in the solutions (69-90\%). The proportion of $\mathrm{MnSO}_{4 a q}$ decreased from $28 \%$ to $0.72 \%$ when $\mathrm{pH}$ increased. The $\mathrm{MnHCO}_{3}{ }^{+}$species appears in the solutions with $\mathrm{pH} \geq 5.09$.

The $\mathrm{CuCO}_{3}$ is predominant species in the solutions with $\mathrm{pH} \leq 7.10$ with a small proportion of $\mathrm{CuHCO}_{3}+$. The shares of $\mathrm{Cu}^{2+}$ are meaningful at the $\mathrm{pH} \leq 7.41$. The $\mathrm{Cu}(\mathrm{OH})_{2}$ is predominant species in solutions at $\mathrm{pH} \geq 7.2$. In the range of $\mathrm{pH}$ 7.43-7.5 the fluoride species $\mathrm{CuF}^{+}$becomes predominant.

In the absence of $\mathrm{F}$ in solutions, $\mathrm{Zn}^{2+}$ is predominant species, in other case $\mathrm{ZnF}^{+}$(concentrations of $\mathrm{F}$ are in the range of $0.24-0.33 \mathrm{mg} / \mathrm{l}$ ) is the predominant species. The shares of $\mathrm{ZnSO}_{4 a q}$ and $\mathrm{ZnHCO}_{3}{ }^{+}$are meaningful in the solutions where $\mathrm{Zn}^{2+}$ is predominant species. The proportion of $\mathrm{ZnSO}_{\text {taq }}$ slowly increased when $\mathrm{pH}$ increased [4]. 
After the intensive oxidation procedure $\mathrm{Zn}^{2+}$ and $\mathrm{Cu}^{2+}$ are the predominant species with a meaningful proportion of $\mathrm{MeSO}_{4}{ }^{0}$ (up to $20 \%$ ) in the solutions at $\mathrm{pH} \leq 5.09$.

For $\mathrm{Pb}$ as well as $\mathrm{Cu}, \mathrm{PbCO}_{3 a q}(36 \%)$ and $\mathrm{PbHCO}_{3}{ }^{+}(13 \%)$ are predominant species with a meaningful proportion of $\mathrm{Pb}^{2+}(30 \%)$ and $\mathrm{PbSO}_{4 a q}(21 \%)$. $\mathrm{Ni}^{2+}$ are predominant species with a meaningful shares of $\mathrm{NiCO}_{3}{ }^{0}(55 \%)$ and $\mathrm{NiSO}_{4}{ }^{0}(13 \%)$. The $\mathrm{NiCO}_{3}$ is the predominant species with a meaningful share of $\mathrm{Ni}^{2+}$ in the solutions at $\mathrm{pH}>6.53$.

WATEQ4F equilibrium calculations indicated that water samples were undersaturated with respect to calcite, siderite, and all other carbonate minerals. It means that the carbonates minerals will be fully dissolved and $\mathrm{Al}$ and $\mathrm{Fe}$ (oxy) hydroxides will be precipitated. Nevertheless, geochemical equilibrium calculations indicated that samples were undersaturated with respect to gibbsite and ferrihydrite when $\mathrm{pH}$ decreases below 4.5. Only more thermodynamically stable crystalline minerals like goethite and hematite may persist. Model calculations indicated undersaturation with respect to the metals $\mathrm{Zn}, \mathrm{Cu}, \mathrm{Pb}$ - and oxyanions bearing phases. Sorption of trace metals on the hydrated surface of the hydroxides and oxides of $\mathrm{Fe}, \mathrm{Al}$ and $\mathrm{Mn}$ may be important control on trace metal concentrations [4].

WATEQ4F calculations indicated occurrences of sulfate complexes of the elements, which could precipitate by hydrolysis. This resulted in a higher concentration of $\mathrm{Al}, \mathrm{Fe}$ and $\mathrm{Mn}$ in the solution. It was also determined that the copper, zinc, cadmium ions occur mainly in the form of hydrated cations of formula $\mathrm{Me}\left(\mathrm{H}_{2} \mathrm{O}\right) 6^{2+}$ [4].

Several authors have reported that nanosized iron oxide particles can be recovered from acid mine drainage and could be used as low-cost sorbents [9]. In systems with neutralization capacity, suspended transport plays an important role, and suspended load may be a more important contaminant transport mechanism than dissolved load.

Consequently after inflow of mine drainage (site M2) the concentration of heavy metals in water of river increased with exception iron. Under the change $\mathrm{pH}$ value and dissolved oxygen predominant species of $\mathrm{Al}, \mathrm{Fe}$ and $\mathrm{Mn}$ are the hydroxides that precipitate as sediment. The heavy metals absorbed by their hydrated surface. This procedure can lead decreasing the content of heavy metals in water at site M3-M5. The increase of concentration of metals in water at site M6, M7 due drainage from mine waste.

\subsection{REE}

The samples of water at site M1 are characterized by deeper negative $\mathrm{Ce}$ anomalies $\left(\mathrm{Ce} / \mathrm{Ce}{ }^{*}=\right.$ 0.30-0.32) than at the site M7 $\left(\mathrm{Ce} / \mathrm{Ce}^{*}=0.66-0.68\right)$. At the site $\mathrm{M} 7$ samples have positive $\mathrm{Eu}$ anomalies $\left(\mathrm{Eu} / \mathrm{Eu}^{*}=2.15-2.17\right)$, but samples of the site $\mathrm{M} 1$ show a low or lack positive Eu anomalies $\left(\mathrm{Eu} / \mathrm{Eu}^{*}=0.93-1.07\right)$. The samples of water (sites M1 and M7) are enriched low by HREE relative to LREE, $(\mathrm{La} / \mathrm{Yb})_{\mathrm{N}}=0.80-0.97$. The samples of mine water are characterized by positive Eu anomalies $\left(\mathrm{Eu} / \mathrm{Eu}^{*}=1.22-1.25\right)$ and low or lack negative Ce anomaly $\left(\mathrm{Ce} / \mathrm{Ce}^{*}\right)_{\mathrm{N}}=0.95$. In the mine water HREE dominate over LREE, $(\mathrm{La} / \mathrm{Yb})_{\mathrm{N}}=0.39-0.42$ (Fig. 6).

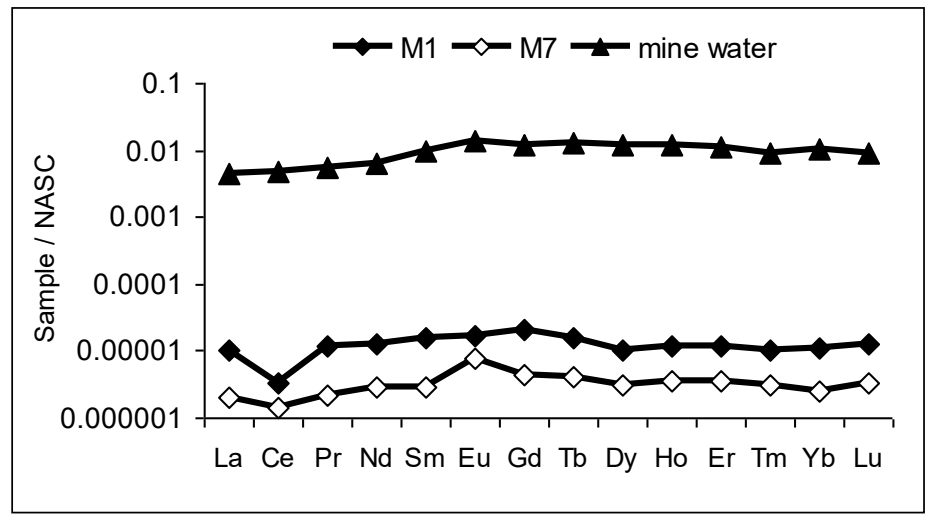

Figure 6. NASC-normalized REE patterns of river Modonkul at site M1, M7 and mine water. 
It follows that the mine water affects on the composition of REE in Modonkul water. It is note at the mouth of river Modonkul (site M7) positive Eu anomalies are more than in inflow mine water upper the site M2 due the drainage from mine waste.

\section{Conclusions}

(1). The spatial variation of the composition water $\mathrm{r}$. Modoncul are revealed the conversion from absolutely bicarbonate to predominant proportion of sulfate among the anions. The difference of chemical composition in river has close relationship with the flux of the recharged inflows. The spatial variation of hydrochemistry showed the influence of mine water and drainage from mine waste.

(2). The mixing of acid mine waters with natural river water has lead to the changes $\mathrm{pH}$ values and physical and chemical processes such as oxidation, adsorption. The predominant species of $\mathrm{Al}, \mathrm{Fe}$ and $\mathrm{Mn}$ are the hydroxides that precipitate as sediment. The heavy metals absorbed by their hydrated surface due the decreasing the content of heavy metals in water in downstream after the confluence of river and inflows. In water systems with neutralization capacity, suspended transport plays an important role.

(3). The mine water affects and dominates on the composition of REE in river water. The content of REE are showed the predominant impact of mine water on the formation chemical composition of river Modoncul.

Funding: This study was performed within the state tasks of GIN SB RAS. The investigations has been conducted within the fundamental research framework of the GIN SB RAS (reg. number AAAA-A17-117021310076-3). This work was financially supported by Grant from Russian Foundation for Basic Research (Siberia), project no. 18-45-030003 (principal investigator A.M. Plyusnin).

Author Contributions: Z.I.K. wrote the text of the article, conducted research as well as in editing and translating the text. A.M.P. assisted in research and providing funding. S.S.S. assisted in research and sample preparation.

Conflicts of Interest: The authors declare no conflict of interest.

\section{References}

1. Gordienko, I.V.; Gorochovsky, D.V.; Smirnova, O.K.; Lantseva, V.S.; Badmatsyrenova, R.A.; Orsoev, D.A. Dzhida Ore District: Geology, Structural and Metallogenic Regionalization, Genetics Types of Ore Deposits, Geodynamics Conditions of their Formation, Forecast and Outlook for Development. Geol. Ore Depos. 2018, 60, pp. 3-37. doi: 10.7868/S001677701801001X (In Russian)

2. Reyf, F.G. Ore-Forming Potential of Granites and Conditions for Its Realization; Nauka: Russia, 1990; p. 180 (In Russian)

3. Khodanovich P.Y.; Smirnova O.K. Tungsten Beresites and Local Forecast of Mineralisation; Nauka Publ: Novosibirsk, Russia, 1991; p. 208 (In Russian)

4. Abrosimova, N., Gaskova, O., Loshkareva, A., Edelev, A., Bortnikova, S. Assessment of the acid mine drainage potential of waste rocks at the Ak-Sug porphyry Cu-Mo deposit. Journal of Geochemical Exploration, 2015, 157, pp. 1-14, DOI: 10.1016/j.gexplo.2015.05.009

5. Abrosimova, N., Modabberi, S., Alizabegan, A., Mirnejad, H., Esmaeilzadeh, E. Prediction of AMD generation potential in mining waste piles, in the Sarcheshmeh porphyry copper deposit. Iran. Environ. Monit. Assess, 2013, 185, pp. 9077-9087.

6. Wei, X., Wolfe, F.A., Han, Y. Mine drainage characterization, treatment, modeling, and environmental aspect. Water Environ. Res., 2014, 86(10), pp. 1515-1534.

7. Yurkevich, N.V., Saeva, O.P., Pal'chic, N.A. Arsenic mobility in two mine tallings drainage systems and its removal from solution by natural geochemical barriers. Appl. Geochem., 2012, 27, pp. 2260-2270.

8. State control of water quality. Handbook of the technical committee for standardization, 2nd ed.; Moscow, IPK Standards Publishing House, 2003, 776 p. (In Russian)

9. Flores, R.G., Andersen, S.L.F., Maia, L.K.K., Jose, H.J., Moreira, R.F.P.M. Recovery of iron oxides from acid mine drainage and their application as adsorbent or catalyst. J. Environ. Manag. 111, pp. 53-60. 
(C) 2019 by the authors. Submitted for possible open access publication under the terms and conditions of the Creative Commons Attribution (CC BY) license (http://creativecommons.org/licenses/by/4.0/). 